\title{
THE ATTITUDES TOWARD CODES OF ETHICS: DO CYNICISM AND RELIGIOSITY MATTERS?
}

\author{
Martinus Parnawa Putranta \\ Graduate School, Universitas Atma Jaya Yogyakarta, Indonesia \\ Email: parnawa@staff.uajy.ac.id
}

Received: December 2019; Accepted: December 2019; Available online: January 2020

\begin{abstract}
The prevalence of corporate transgressions in Indonesia have brought the moral standards of business leaders into public domain. In light of these phenomena, an investigation into whether prospective business leaders of the country are predisposed to moral values is crucial. The purpose of this research was to ascertain the attitudes of the Indonesian future business leaders towards the existence of codes of ethics in business. In particular, the research examined whether the religious orientation of these future leaders influenced the attitudes. A test was also assigned to scrutinize whether the degree of their social cynicism moderated that possible causal relationship. A survey was used as the primary method to collect the data. The sample involved first-year students from a business school at a private university in Indonesia. A total of 111 students involved in the survey. Results of the research showed majority of the respondents were generally to have positive attitudes towards codes of ethics. The intrinsic religious orientation of the students also had a positive impact on the attitudes. This positive relationship, however, was mitigated by their negative views of people and social institutions. Managerial implications of the research findings are discussed and the directions of future similar research are outlined.
\end{abstract}

Keywords: codes of ethics, intrinsic religiosity, social cynicism, first-year students, Indonesia.

\begin{abstract}
Abstrak
Berbagai pelanggaran perusahaan yang banyak dijumpai di Indonesia mengakibatkan standar moral para pemimpin bisnis menjadi perbincangan publik. Fenomena ini membuat studi tentang kecenderungan nilai-nilai moral para calon pemimpin bisnis di Indonesia di masa masa depan menjadi sangat penting. Tujuan dari penelitian ini adalah untuk mengetahui sikap para calon pemimpin bisnis tersebut terhadap keberadaan kode etik dalam dunia bisnis. Secara khusus, penelitian ini menguji apakah orientasi keagamaan para calon pemimpin bisnis tersebut mempengaruhi sikap mereka terhadap keberadaan kode etik dalam bisnis. Pengujian juga dilakukan untuk mengetahui apakah pengaruh yang dimaksud dimoderasi oleh pandangan negatif terhadap terhadap situasi sosial (sinisme sosial) dari para calon pemimpin bisnis tersebut. Survei digunakan sebagai metode utama untuk pengumpulan data. Sampel dalam penelitian ini adalah mahasiswa tahun pertama di fakultas bisnis dari satu universitas swasta di Indonesia. Sebanyak 111 mahasiswa tahun pertama berpartisipasi dalam survei tersebut. Hasil penelitian menunjukkan mayoritas responden memiliki sikap positif terhadap keberadaan kode etik dalam dunia bisnis. Orientasi religiusitas intrinsik terbukti berpengaruh positif terhadap sikap tersebut. Namun, pengaruh positif ini diperlemah oleh tingkat sinisme sosial mereka. Implikasi manajerial dari temuan penelitian dibahas dan arah penelitian serupa di masa depan diuraikan dalam artikel ini.
\end{abstract}

Kata kunci: kode etik, religiusitas, sinisme sosial, mahasiswa tahun pertama, Indonesia.

How to Cite: Putranta, M. P. (2020). The Attitudes toward Codes of Ethics: Do Cynicism and Religiosity Matters? Media Ekonomi dan Manajemen, 35(1), 128-136. doi: http://dx.doi.org/10.24856/mem.v35i1.1335. 


\section{INTRODUCTION}

The continuos unethical business scandals in Indonesia (e.g. the cases of the formaldehyde-laced noodles, plastic rice and umrah pilgrimage scam) have brought ethics in business into the public domain. More specifically, the ethical standards of business leaders have been called into question by those scandals. From an educational viewpoint, the role of higher education institutions as training grounds for business leaders are challenged. In particular, the institutions are currently required to promote ethical awareness and behaviours among their students who might become the leaders of the future. A crucial step in meeting this objective is to understand their current attitudes toward ethical practices in business and develop strategies to strengthen desirable attitudes and weaken undesirable ones. With this in mind, this research was aimed at assessing the attitudes of first-year business students toward the presence of codes of ethics. This is because codes of ethics have been considered as the most obvious way of securing ethical practices within organisations (Chonko, Wotruba \& Loe, 2003) as they provide explicit guidelines for acceptable and unacceptable conducts for employees in the organizations (Schwartz, 2002). The religiosity of the students was examined to ascertain whether it could serve as a predictor of their attitudes towards the codes. Previous research suggests that a causal relationship between the two variables exists (see, for example, Siu, Dickinson \& Lee, 2000; Singhapakdi, Marta, Rallapalli, \& Rao, 2000; Kurpis, Beqiri, \& Helgeson, 2008). Furthermore, Vitell (2010) argues those who have stronger religious beliefs are more likely to intend to behave ethically even though higher levels of religiosity is not always indicative of higher levels of ethical behaviours (Voegel \& Pearson, 2016). In addition, a test was assigned to ascertain whether social cynical views held by the students moderated the causal relationship between their intrinsic religious orientation and their attitudes towards codes of ethics.

\section{THEORETICAL \\ BACKGROUND AND HYPOTHESES}

\section{Code of Ethics}

As a signal to stakeholders of their concerns of ethics many organisations develop formal written ethical guidelines to regulate behavioural standards within organisations commonly known as codes of ethics (Malloy, Sevigny, Hadjistavropoulos, Jeyaraj, McCarthy, Murakami, Paholpak, Lee \& Park, 2009). While numerous meanings of a code of ethics exist (e.g. Blok, 2013; Kaptein \& Schwartz, 2008; Langlois \& Schlegelmilch, 1990; Preus, 2010; Schwartz, 2001; Singh, 2011) those various meanings share a common idea that a code of ethics is a written and formal document consisting ethical principles to guide employees' behaviours. In literature, codes of ethics sometimes described by other names such as codes of conduct, ethical guidelines and operating principles (Kleynjans \& Hudon, 2016; Yallop, 2012) Unlike codes of conduct, however, codes of ethics contain general main principles and no imperative in nature (Tauginienè, 2016).

Attitudes towards Codes of Ethics among first-year business students

Understanding ethical attitudes among first-year business students is important as they might become future leaders who will be involved in resolving ethical challenges. While the attitudes of future business leaders towards a code of ethics do not promise their actual ethical behaviours, exploring their attitudes will be beneficial to understand their possible ethical conducts.

Unfortunately, empirical support for such an investigation is lacking. The most recent investigations on business students' attitudes towards the concept of codes of ethics were conducted by Peppas, Yu, 
Zhang \& Peppas (2017), Peppas \& Yu (2009), and Peppas (2003). However, none of these studies specifically tapped possible roles of the students' religiosity and social cynicism play in developing the attitudes. In addition, to date there has been no research examining this issue among first-year business students in Indonesia. This research aimed to fill this gap.

\section{Religiosity}

Religiosity is defined as "a belief in God accompanied by a commitment to follow principles believed to be set forth by God" (McDaniel \& Burnett, 1990, p. 110). Religiosity has been believed to have an influence on people' attitudes (Conroy \& Emerson, 2004; Voegel \& Pearson, 2016; Walker, Smither \& DeBode, 2012; Weaver \& Agle, 2002) in that believers in God are less willing to act unethically because they believe that an omniscient God will know their unethical thought or attitudes (Conroy \& Emerson, 2004) although higher levels of religiosity does not necessarilly lead to higher levels of ethical behaviour ((Voegel \& Pearson, 2016). In their book, Hill and Hood (1999) outlined numerous scales of religiosity. However, one of the most well known and extensively used is the Allport and Ross's (1967) Religious Orientation Scale (Kurpis et al., 2007; Maltby \& Lewis, 1996; Vitell, 2010). Allport and Ross proposed two distinct dimensions of religiosity, namely, an intrinsic and an extrinsic religiosity. Persons with an extrinsic religious orientation use their religion to obtain emotional comfort, social support for personal gain (Merill, Steffen \& Hunter, 2012) or further a business agenda (Patwardhan, Keith \& Vitell, 2012). Hence, they tend to use religion for their own ends (Kurpis et. Al, 2007). Intrinsically motivated religious persons, on the other hand, internalise their religious beliefs and are motivated to live their religions in all aspects of their daily life (Wong, 2008). Therefore, they view their religions is an end itself (Kurpis et al.,
2007; Merill et al., 2012). These different characteristics suggest that suggest that intrinsically religious people are much more likely to use their religious beliefs as a guide for their day-to-day decisions (Walker et al., 2012), hence, it is more likely to expect a positive link between intrinsic religiosity and ethical attitudes (Kurpis et al. , 2007; Patwardhan, et al., 2012; Voegel \& Pearson, 2016). Previous research (Kurpis et al., 2007; Patwardhan, et al., 2012; Wong, 2008) have confirmed a similar positive association. Based on the aforementioned considerations, the following hypothesis is formulated:

H1: Intrinsic religiosity is a positive determinant of attittudes towards codes of ethics.

Extrinsically religious people are engaged in religion as a means to an end, therefore, they are less likely to look to their religious role expectations as a cognitive framework to guide them in their day-to-day behaviours (Walker et al., 2012). Considering this immature and selfish characteristics, extrinsic religiosity sometimes is associated with negative life outmes (Vitell, 2010). That is to say, it may not have strong positive correlation with ethical attitudes. Previous research (Patwardan et al., 2012; Wong, 2008) appears to support this notion. Therefore:

$\mathrm{H} 2$ : Extrinsic religiosity is not a significant determinant of attitudes towards codes of ethics.

\section{Social Cynicism}

The term cynicism originated in the $4^{\text {rd }}$ century in Greece where a group of philosophers (cynics) believed that freedom to attack popular beliefs for their personal interests is a privilege that human beings enjoy (Levent \& Keser, 2016). Basically, cynicism is a philosophical view about human nature that considers others cannot be trusted to be reliable and genuine (Chowdhury \& Fernando, 2014). It is described as an attitude toward an entity (Nair \& Kamalanabhan, 2010), therefore, 
cynicism is a dispositional construct that evaluative in nature as it assesses the world and people in terms of good and evil (Stavrova \& Ehlebracht, 2016).

Cynicism has been classified into five categories (see, for example. Chowdhury \& Fernando, 2014; Turkmen \& Aykac, 2017). The first category is personality cynicism describing the negative perception of human behaviour that unchangeable. The second is social cynicism which basically disappointment about society, its institutions and other elements. The third is labelled employee cynicism, a negative attitude towards various aspects of workplaces managers, as a result of, for example, working hours and leadership. The fourth is named job or vocational concerning with low status of a profession. The last one is organisational change cynicism is defined as a pessimistic viewpoint about the success of change efforts

Social cynicism refers to negative beliefs about people, social groups, social institutions, spiritual world as well as events in the social world which may negatively impact on people's affective reaction (Li, Zhou \& Leung, 2011). Such a view is more likely to be found in societies where general mistrust of social systems and people are prevalent (Aqueveque \& Encina, 2010) which seems to be the case of Indonesia given the aforementioned unethical business scandals. People with high social cynical view not only reject ethical values (Li et al., 2011), but they also mistrust the motives behind the actions of institutions and individuals (Aqueveque \& Encina, 2010). Therefore, it is less likely to expect a positive association between social cynical view with the attitudes towards the creation of codes of ethics. A previous research (Brands, Bronkhorst \& Welie, 2011; Valentine \& Elias, 2005) has confirmed this negative association. Considering all of these findings, the following hypothesis is set forth:

H3: Social cynicism is a negative determinant of attitudes towards codes of ethics.

Given its negative influence on ethical attitudes, it is likely to envisage that social cynicism mitigate the positive relationship between intrinsic religiosity with attitudes towards codes of ethics. That is, the higher level of social cynicism, the lower the positive effect (Walker et al., 2012; Wong, 2008) of intrinsic religiosity on attitudes towards codes of ethics. Therefore:

H4: Social cynicism moderates the influence of intrinsic religiosity on attitudes towards codes of ethics.

\section{RESEARCH METHODS}

Sample

The sample of this study involved first-year students from a business school at a denominational university in Indonesia. A total of 150 questionnaires were distributed during class meeting at the university of which 111 were usable, representing an overall response rate of 74 $\%$. The respondents were equal in gender, with $57(51.3 \%)$ male and $54(48.7 \%)$ female students. The majority of the respondents ( 92 or $82.9 \%$ ) were less than 20 years while the rest $9(17.1 \%)$ were above 20 years old. The majority of the respondents (75 or $67.6 \%$ ) were Catholic. The other respondents reported their religions as Protestant (25 or 22.5\%) and Islam (11 or $9.9 \%)$.

\section{Measures}

A seven-item scale devised by Peppas (2003) was used to measure attitudes towards codes of ethics. Students were instructed to assume that a code of ethics was set up in the organisations they were willing to work and were asked to show their levels of agreement/disagreement with the seven statements regarding the possible impact of the existence of the 
code. Religiosity was measured by using an adopted 20 -item scale developed by Allport and Ross (1967). Nine items of the scale represent intrinsic religiosity while the other 11 items tap extrinsic religiosity. Social cynicism was measured by four items from Seriki,, Evans, Jeon, Rajiv, and Helm (2016). All scales used in this research were measured using five-point Likert scales ranging from 1 (strongly disagree) to 5 (strongly agree).

\section{RESULTS AND DISCUSSION Results}

A series of Exploratory Factor Analysis (EFA) were performed on the three scales to the whole sample $(\mathrm{N}=111)$. Results of EFA suggested 7 items of religiosity scale were eliminated for psychometric considerations. Details of the remaining 13 items and their respective factors are reported in Table 1.

As shown in the table, the eigenvalue of each factor was greater than the recommended value of 1.00 (Hair, Black, Babin, Anderson, \& Tatham, 1998). The factor loading coefficient of each item to its respective factor was above the acceptable limit of 0.50 (Hair et al. 1998).

\section{Reliability and validity}

As shown in Table 2, values of Cronbach's alpha for all constructs are greater than the recommended value of 0.70 , indicating the reliability of all constructs used in this research were assured. All individual constructs had eigenvalues exceeding 1.00 (Hair et al., 1998) indicating that the convergent validity of each construct was confirmed. The individual alpha coefficients were higher than the correlation coefficients across all constructs, suggesting the discriminant validity of the measurement models was assured (Sharma \& Patterson, 1999).

To examine whether attitudes towards codes of ethics could be explained by intrinsic religiosity and extrinsic religiosity multiple regression analysis was employed. As shown in Table 3, only the intrinsic religiosity significantly predict their attitudes towards the codes of ethics. Thus, hypothesis 1 is supported while hypothesis 2 is not. Compared to its extrinsic counterpart, intrinsic religiosity by nature leads to the internalisation of religion-endorsed norms hence it provides a better opportunity to link it with ethical attitudes (Kurpis et al., 2012).

To test whether social cynicism moderate the influence of intrinsic religiosity on attitudes towards codes of ethics a moderated regression analysis was utilized. Basically, the test seeks to determine the change in $\mathrm{R}^{2}$ that results during a hierarchical test of two regression equations (see Table 4). Basically, the test seeks to determine the change in $\mathrm{R}^{2}$ that results during a hierarchical test of two regression equations. In the first regression the dependent variable of the attitudes towards codes of ethics is regressed on intrinsic religiosity as the independent variable. As shown in Table 4 (column 2) findings of the test show a significant $\mathrm{R}^{2}$ of 0.288. Then, a second regression of attitudes towards codes of ethics with both the independent variable of intrinsic religiosity and the moderator variable of social cynicism follows. As seen in the same table the results indicate a higher R2 of 0.363 . The increase in $\mathrm{R}^{2}$ from 0.288 to 0.363 is statistically significant $(\mathrm{F}=$ 50.757; $\mathrm{p}<0.001)$. Thus, Hypothesis 3 is supported. 
Table 1. Summary of Exploratory Factor Analysis Results

\begin{tabular}{lccccc}
\hline Construct & Items & $\begin{array}{c}\text { Loadings } \\
\text { (range })\end{array}$ & $\begin{array}{c}\text { Communalities } \\
\text { (range) }\end{array}$ & $\begin{array}{c}\text { Eigen } \\
\text { Value }\end{array}$ & Alpha \\
\hline Attitudes towards Codes of Ethics & 7 & $0.634-0.778$ & $0.407-0.606$ & 3.112 & 0.783 \\
Extrinsic Religiosity & 7 & $0.652-0.793$ & $0.411-0.881$ & 4.176 & 0.879 \\
Intrinsic Religiosity & 6 & $0.591-0.775$ & $0.405-0.532$ & 3.184 & 0.781 \\
Social Cynicism & 3 & $0.655-0.817$ & $0.429-0.643$ & 2.262 & 0.739 \\
\hline
\end{tabular}

Table 2. The inter-correlation coefficients of the variables used in the research

\section{Construct}

$1 \quad 3 \quad 4$

1. Attitudes Toward Code of Ethics

2. Intrinsic Religiosity

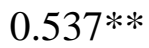

3. Extrinsic Religiosity

4. Social Cynicism

$-0.426 * *$

$-0.100$

Mean

3.513

$-0.301 * *$

0.051

Cronbach's alpha

0.783

3.792

3.390

3.459

0.879

0.781

0.739

** significant at the 0.01 level (2-tailed)

Table 3. Regression analysis for predicting attitudes towards codes of ethics from intrinsic religiosity and extrinsic religiosity

\begin{tabular}{lccccc}
\hline & $b$ & $S E$ & $\beta$ & $\mathrm{t}$ & Sig \\
1. Constant & 1.968 & 0.265 & & 7.428 & $0.000^{* *}$ \\
2. Intrinsic Religiosity (total) & 0.448 & 0.054 & 0.531 & 8.373 & $0.000^{* *}$ \\
3. Extrinsic Religiosity (total) & -0.044 & 0.044 & -0.065 & -1.019 & 0.310 \\
\hline
\end{tabular}

* significant at the 0.01 level (2-tailed)

Table 4. Attitudes towards codes of ethics predicted from intrinsic religiosity and social cynicism

\begin{tabular}{ccccccc}
\hline Model & $\mathrm{R}$ & $\mathrm{R}^{\mathbf{2}}$ & Adjusted $^{\mathbf{2}}$ & SE Est & $\Delta \mathrm{R}^{\mathbf{2}}$ & Sig F change \\
\hline 1 & 0.537 & 0.288 & 0.284 & 0.480 & 0.288 & 0.000 \\
2 & 0.603 & 0.363 & 0.356 & 0.456 & 0.072 & 0.000
\end{tabular}

\section{Discussion}

Results of this research provide evidence that the intrinsic religious orientation of first-year business students might lead to more positive of their attitudes towards codes of ethics. On the other hand, their extrinsic religious orientation did not seem to influence on such attitudes. In addition, their cynical views towards people and social institutions (or social cynicism) have a negative influence on those attitudes. Despite this negative effect, social cynicism was also shown to have potential to mitigate the positive influence of the students' intrinsic religiosity on their attitudes towards codes of ethics. In the context of business ethics education, promoting active participation in students' religions of choice and lessening their cynical views of people and social institutions might become variables affect the success of educational interventions. It is noteworthy that religiosity in this context is not concerned with which religions the students associate (Voegel \& Pearson, 2016) but it refers to the extent to which the students follow the principles of their religion. Considering the sampled institution in this research was a denominational university where religion is a compulsory unit for students, promoting such participation through that unit is possible. The idea indeed is not to 
assume religious persons and ethical people are equivalent. Instead, it aims to develop characters by providing reasons for ethical positions that are compatible with religious views. That is to say, the promotion is aimed at helping students understand why specific behaviors are good or bad from both religious and ethical point-of-view. Therefore, it is not simply to help students follow the dictates of religious values. Of course, this is not easy given most religious texts were written at a time when many of today's most challenging moral questions were implausible. If this is to be the case, secular ethics might be necessary. Using films showing ethically questionable behavior to students or inviting practitioners or professionals from institutions with high levels of ethical reputation might help lessen the cynical views of students that business ethics is not oxymoron. The full effects of this classrooms experience indeed do not take hold until students have spent time in their respective positions.

\section{Limitations}

The foremost limitation of this research concerned the use of a single institution and socially desirable responses considering the sensitive nature of the topic. Similar research on other first-year business and non-business students from other denominational, non-denominational and public universities may help provide a more precise description of the attitudes towards ethics of these future leaders. In addition, the results may not indicative of their actual behaviours when they face ethical dilemma in their workplace in the future.

\section{CONCLUSIONS}

This research contributes to a better understanding of who the future leaders of the sampled institution are in terms of their religiosity, attitudes towards codes of ethics and on their way of perceiving the world around them. Findings of the research suggest universities should take proactive actions to provide opportunities their first-year students to internalise their religious values that correspond with ethical behaviours in the hope that they can develop character dispositions that enable the promotion of virtues that support a good business.

\section{REFERENCES}

Allport, G. \& Ross, J. (1967). Personal religious orientation and prejudice. Journal of Personality and Social Psychology, 2, 423-443.

Aqueveque, C. \& Encina, C., (2010). Corporate behavior, social cynicism, and their effect on individuals' perceptions of the company. Journal of Business Ethics, 91(2), 311-324.

Brands, W.G., Bronkhorst, E.M. \& Welie, J.V.M. (2011). Professional ethics and cynicism amongst Dutch dental students. European Journal of Dental Education, 5(2), 205-209.

Blok, V. (2013). The power of speech acts: Reflections on a performative concept of ethical oaths in economics and business. Review of Social Economy, 71(2), 187-208

Chonko, L. B., Wotruba, T. R., \& Loe, T. W. (2003). Ethics code familiarity and usefulness: Views on idealist and relativist managers under varying conditions of turbulence. Journal of Business Ethics, 42(3), 237-252.

Chowdhury, R. \& Fernando, M. (2014). The Relationships of Empathy, Moral Identity and Cynicism with Consumers' Ethical Beliefs: The Mediating role of moral disengagement, Journal of Business Ethics, 124(4), 677-694 
Conroy, S.J. \& Emerson, T.L.N. (2004). Business ethics and religion: religiosity as a predictor of ethical awareness among students. Journal of Business Ethics, 50(4), 383-396.

de Vaus, D.A. (2007). Surveys in social research, $\left(7^{\text {th }}\right.$ ed.). Crows Nest: Allen \& Uwin.

Hair, J.F. Jr., Black, W.C., Babin, B.J., Anderson, R.E., \& Tatham, R.L., (1998). Multivariate data analysis $\left(6^{\text {th }}\right.$ ed.) Upper Saddle River: Prentice-Hall.

Hill, P.C. \& Hood, R.W. (1999). Measures of religiosity. Birmingham, $\mathrm{AL}$ : Religious Education Press.

Kleynjans, L. \& Hudon, M. (2016). A Study of Codes of Ethics for Mexican Microfinance Institutions. Journal of Business Ethics 134 (3), 397-412

Kurpis, L.V, Beqiri, M.S., \& Helgeson, J.G. (2008). The effects of commitment to moral self-improvement and religiosity on ethics of business students. Journal of Business Ethics, 80(3), 447-463.

Langlois, C.C. \& Schlegelmilch, B.B (1990). Do corporate codes of ethics reflect national character? Evidence from Europe and the United States. Journal of International Business Studies 21(Fourth Quarter): 519-536.

Levent, F. \& Keser, S. (2016). Examining the organizational cynicism among teachers at schools: A mixed methods study. Educational Research and Reviews 11, 20092020.

Li , F. L. , Zhou , F. , \& Leung, K. (2011). Expecting the worst: moderating effects of social cynicism on the relationships between relationship conflict and negative affective reactions. Journal of Business Psychology, 26, 339 - 345.
Malloy, D.C., Sevigny, Hadjistavropoulos, T., Jeyaraj, M., McCarthy, E.F., Murakami, M., Paholpak, S., \& Lee, Y \& Park, I. (2009). Perceptions of the effectiveness of ethical guidelines: An international study of physicians. Medicine, Health Care, and Philosophy 12(4), 373-383.

Maltby, J., \& Lewis, C. A. (1996). Measuring intrinsic and extrinsic orientation toward religion: Amendments for its use among religious and framework. Mental Health, Religion \& Culture, 13, 749759.

McDaniel, S. W. \& Burnett, J. J. (1990). Consumer religiosity and retail store evaluative criteria. Journal of the Academy of Marketing Science, 18, 101-112.

Merrill, R. M., Steffen, P. R., \& Hunter, B. (2012). A comparison of religious orientation and health between Whites and Hispanics. Journal of Religion and Health, 51, 1261-1277.

Nair, P, \& Kamalanabhan, T.J. (2010). The Impact of Cynicism on Ethical Intentions of Indian Managers: The moderating role of their level of management. International Journal of Trade, Economics and Finance. 1 (2), 155-159

Patwardhan, A. M., Keith, M. E., \& Vitell, S. J. (2012). Religiosity, attitude toward business, and ethical beliefs: Hispanic consumers in the United States. Journal of Business Ethics, 110(1), 61-70.

Peppas S.C. \& Yu, T.T (2009). Codes of ethics: A comparison of the attitudes of future managers in China and the USA, Management Research News, 32(4), 383-391.

Peppas, S.C. (2003). Attitudes toward codes of ethics: The effects of corporate misconduct. Management Research News, 26(6), 77-89. 
Peppas, S.C., Yu, T.T., Zhang, M.M. \& Peppas, S.R. (2017). Student Perceptions of Codes of Ethics: A three-country comparison. International Journal of Economics and Business Research 13(1), 43-56.

Preuss, L. (2010). Codes of conduct in organizational context: From cascade to lattice-work of codes. Journal of Business Ethics, 94(4), 471-487

Schwartz, M.S. (2001). The nature and the relationship between corporate codes of ethics and behavior, Journal of Business Ethics, 32, 247262.

Seriki, O., Evans K., Jeon, H.J., Rajiv, D. \& Helm A. (2016). Unintended effects of marketing messages on salesperson cynicism, European Journal of Marketing, 50(5/6), 10471072.

Sharma, N. \& Patterson, P.G (1999). The impact of communication effectiveness and service quality on relationship commitment in consumer, professional services, Journal of Services Marketing, 13(2), 151-170.

Singh, J.B (2011) Determinants of the effectiveness of corporate codes of ethics: An empirical study. Journal of Business Ethics 101 (3): 385 395.

Singhapakdi, A., Marta, J.K., Rallapalli, K.C. \& Rao, C.P. (2000). Toward an understanding of religiousness and marketing ethics: An empirical study. Journal of Business Ethics, 27(4), 305-319.

Siu, N.Y.M., Dickinson, J.R., \& Lee, B.Y.Y. (2000). Ethical evaluations of business activities and personal religiousness. Teaching Business Ethics, 4(3), 239-256.
Stavrova, O. \& Ehlebracht, D. (2016). Cynical Beliefs about Human Nature and Income: Longitudinal and Cross-Cultural Analyses. Journal of Personality and Social Psychology 110 (1) 116 - 132

Tauginienè, L. (2016). Embedding Academic Integrity in Public Universities. Journal of Academic Ethics, 14(4), 327-344

Turkmen, F. \& Aykac, E. (2017). The Association Between Organizational Cynicism and Organizational Citizenship Behavior: A Case Study, European Research Studies Journal, 20 (4A), 742-753.

Valentine, S. \& Elias, R.Z. (2005). Perceived corporate ethical values and individual cynicism of working students. Psychological Reports, 97(3), 832-834.

Vitell, S. J. (2010). The role of religiosity in business and consumer ethics: A review of the literature. Journal of Business Ethics, 90(2), 155-167.

Voegel, J.A., \& Pearson, J. (2016). Religiosity and ethical ideologies as they pertain to business ethics: Through the lens of the theory of planned behavior. Journal of Leadership, Accountability \& Ethics, 13(1), 30-48.

Walker, A. G., Smither, J. W., \& DeBode, J. (2012). The Effects of Religiosity on Ethical Judgments. Journal of Business Ethics, 106(4), 437-452.

Weaver G. R., \& Agle B. R. (2002) Religiosity and ethical behavior in organizations: A symbolic interactionist perspective. Academy of Management Review, 27(1), 77-97.

Wong, H.M. (2008). Religiousness, love of money, and ethical attitudes of Malaysian evangelical Christians in business. Journal of Business Ethics, 81(1), 169-191. 